\title{
Jogo de cena: um outro olhar sobre a entrevista no documentário
}

\author{
Carlos Pernisa Júnior \& Helena Oliveira Teixeira de Carvalho*
}

Resumo: O artigo pretende fazer uma análise das entrevistas presentes no filme Jogo de cena (2007), de Eduardo Coutinho. O documentário traz depoimentos de mulheres anônimas e de atrizes profissionais, porém, em alguns deles, com as mesmas histórias, o que levanta a questão sobre o status de real da entrevista e os limites entre ficção e realidade.

Palavras-chave: documentário; Eduardo Coutinho; entrevista; performance.

Resumen: El artículo pretende hacer un análisis de las entrevistas presentes en la película Jogo de cena (Juego de escena, 2007), de Eduardo Coutinho. El documental trae testimonios de mujeres anónimas y de actrices profesionales, pero con las mismas historias en algunos casos, lo que plantea la cuestión sobre el status de real de la entrevista y los límites entre ficción y realidad.

Palabras clave: documental; Eduardo Coutinho; entrevista; perfomance.

Abstract: The article aims to analyse the interviews in the film Scene Game (2007), by Eduardo Coutinho. The documentary gathers testimonials from anonymous women and professional actresses, but in some of them, regarding the same stories, which raises the question about the real status of the interview and the boundaries between fiction and reality.

Keywords: documentary; Eduardo Coutinho; interview; performance.

Résumé : Cet article propose une analyse des entretiens réalisés dans le film Game (2007), d'Eduardo Coutinho. Le documentaire comprend des témoignages de femmes anonymes et d'actrices professionnelles, mais certains d'entre-eux relatent des histoires similaires, ce qui pose la question du statut réel de l'entretien et des frontières entre la fiction et la réalité.

Mots-clés : documentaire ; Eduardo Coutinho ; entretien ; performance.

* Carlos Pernisa Júnior. Universidade Federal de Juiz de Fora, Faculdade de Comunicação, Programa de Pós-Graduação em Comunicação. 36036-900, Juiz de Fora, Minas Gerais, Brasil. E-mail: carlospernisajr@gmail.com

Helena Oliveira Teixeira de Carvalho. Mestranda. Universidade Federal de Juiz de Fora, Faculdade de Comunicação, Programa de Pós-Graduação em Comunicação. 36036-900, Juiz de Fora, Minas Gerais, Brasil. E-mail: helena.otc@ gmail.com

Submissão do artigo: 26 de abril de 2017. Notificação de aceitação: 10 de julho de 2017. 


\section{Introdução}

Sempre que pensamos em documentário, temos dificuldades de encontrar uma definição exata sobre o gênero, pois seu significado não pode ser reduzido a um verbete de dicionário como "temperatura" ou "sal de cozinha" (Nichols, 2007). Muitos buscam defini-lo a partir do conceito de realidade, fazendo associação com a ideia de cinema do real. Mas essa associação de documentário com o registro do real é questionável, pois quando a câmera é ligada e posicionada, não conseguimos reproduzir tudo o que está acontecendo naquele momento da filmagem. Então, é escolhida uma parte daquela realidade para ser mostrada, é determinada certa angulação, de acordo com o ponto de vista e com a intenção de quem está filmando ou dirigindo. Portanto, o documentário não pode ser considerado uma reprodução, mas sim uma representação do real.

O cinema documental também é caracterizado por diferenciar-se do cinema de ficção, uma vez que aborda o mundo em que vivemos e não um imaginado pelo cineasta (Nichols, 2007) como acontece nos filmes ficcionais. Contudo, ficção e documentário não apresentam diferenças que os separam de maneira absoluta. Ambos usam os mesmos elementos narrativos, como roteiro, atuação, edição, cenário, entre outros. O que difere os dois gêneros é, principalmente, a intenção do autor, pois um cineasta de ficção tem como objetivo entreter o público, sem ter, necessariamente, compromisso com a realidade, ao passo que o documentarista faz asserções sobre o mundo real, trazendo questões do nosso cotidiano que precisam ser abordadas e discutidas.

O documentário apresenta diferentes formas de colocar suas proposições, variando-as historicamente. Até a década de 1950, no chamado documentário clássico ${ }^{1}$ havia uma predominância da voz over ou "voz de Deus", que é uma voz que faz uma locução narrando os fatos de acordo com o que é exibido nas imagens. A partir da década de 1960, com o surgimento do cinema direto/verdade em que a história é contada através de diálogos, o documentário passou a apresentar uma nova maneira de colocar suas asserções, através de entrevistas e depoimentos, o que, ao longo do tempo, passou a ser um dos elementos centrais da narrativa documental. É nesse contexto também que a entrevista passou a ser trabalhada como um artifício de real nas narrativas audiovisuais, principalmente no cinema documentário e no jornalismo: “(...) é raro o produto audiovisual que não lance mão da entrevista como elemento

1. Também denominado cinema etnográfico, ganhou notoriedade na Escola Inglesa, especialmente com John Grierson, podendo ser conceituado como cinema de propaganda, financiado pela indústria e pelo governo, cuja função inicial era educativa e social. Suas principais características eram utilização intensa de voz over expositiva e encenação (Fernão Pessoa Ramos, 2004). 
fundamental para contextualizar e garantir o status de verdade que caracteriza os gêneros telejornalístico e documental" (Musse e Musse, 2010).

Seguindo essa tendência de exploração de depoimentos orais, porém com o foco voltado para as histórias de vida de pessoas comuns, majoritariamente das classes menos favorecidas economicamente, o cineasta e diretor Eduardo Coutinho teve papel de destaque no cenário do documentário contemporâneo nacional. Considera-se que os filmes do diretor têm um diferencial em relação aos demais documentários, o que se dá pela forma como o diretor conduz a entrevista, deixando sempre o entrevistado à vontade e convencendo-o a se abrir com ele; pelo tratamento dado às imagens - câmera fixa no entrevistado, alternando apenas os planos - e pela montagem simples, contendo basicamente apenas os depoimentos, com pouca trilha sonora, voz over e imagens externas, elementos que, em algumas obras, chegam a ser inexistentes.

Contudo, o filme Jogo de cena (2007), de Eduardo Coutinho, foco do presente trabalho, coloca em questionamento esse status de verdade da entrevista e os limites entre ficção e não-ficção. O longa-metragem traz as histórias de vida de 23 mulheres, narradas pelas próprias em entrevistas ao diretor. Entretanto, a narrativa também traz depoimentos de atrizes profissionais contando histórias de vidas, em alguns momentos as mesmas que as mulheres anônimas, o que faz com que o espectador se pergunte quem está interpretando e a quem pertencem aquelas histórias, tendo que desvendar assim o jogo criado pelo cineasta.

O propósito desse artigo é analisar as entrevistas presentes em Jogo de cena e a construção narrativa do filme, para entender como esse status de real e os limites entre o cinema de ficção e o documental foram trabalhados. Para isso, recorreremos a uma breve análise do documentário brasileiro e da obra de Eduardo Coutinho, assim como um estudo da "performance" no filme em questão, a partir de autores como Jean-Claude Bernardet, Fernão Pessoa Ramos, Ismail Xavier e Cláudio Bezerra.

\section{Documentário à moda brasileira}

Os primeiros filmes nacionais com características documentárias surgem em meados dos anos de 1920. Nesse primeiro momento - que vai até a chegada do Cinema Novo -, o documentário brasileiro desenvolve-se em torno do Ince (Instituto Nacional do Cinema Educativo), e de um dos principais diretores da época, Humberto Mauro ${ }^{2}$. Nesse período, os filmes documentais

2. Humberto Mauro dirigiu filmes de ficção que fizeram muito sucesso no período do cinema mudo, como Sangue Mineiro (1929) e Ganga Bruta (1933), mas já na ficção as características do documentarista se manifestavam. 
giravam em torno dos registros feitos nas expedições pelas regiões do país e da propaganda, ambos com intuito de mostrar aos estrangeiros as belezas exóticas do Brasil. Também nessa mesma época, o governo de Getúlio Vargas, seguindo tendências europeias, vinculou o cinema a fins culturais de acordo com os interesses do governo, dando-lhe um caráter educativo e panfletário.

Na década de 1960, surge, na Europa, um novo estilo cinematográfico, o chamado cinema verdade/direto. Segundo Fernão Pessoa Ramos (2004: 81), esse novo modelo faz parte da primeira ruptura ideológica com o estilo de filme documentário caracterizado por "utilização intensa de voz over expositiva, encenação e um namoro sem má consciência com a propaganda", até então dominante, o que influenciou na história de todo o cinema.

$\mathrm{O}$ cinema verdade/direto teve grande influência na produção brasileira. $\mathrm{O}$ seminário de cinema organizado pela Unesco e pela Divisão de Assuntos Culturais do Itamaraty, no segundo semestre de 1962, é classificado como o grande marco da nova fase do documentário no Brasil. "O documentarista ArneSucksdorff (que veio ao Brasil portanto dois gravadores Nagra), foi, segundo Fernão Ramos, o responsável por fazer com que a geração do Cinema Novo tivesse contato com o som direto e suas técnicas" (Musse, 2012, p.40). Mesmo que em um primeiro momento ainda houvesse dificuldades técnicas para sincronizar a imagem ao áudio, percebe-se um entusiasmo com a possibilidade de entrevista entre os documentaristas ligados ao Cinema Novo, que começam a produzir seus primeiros filmes a partir da nova captação do som direto.

O Cinema Verdade/Direto revoluciona a forma documentária, através de procedimentos estilísticos proporcionados por câmeras leves, ágeis e, principalmente, o aparecimento do gravador Nagra. Planos longos e imagem tremida com câmera na mão constituem o núcleo de seu estilo. O aparecimento do som direto conquista um aspecto do mundo (o som sincrônico ao movimento) que os limites tecnológicos havia, até então, negado ao documentário. Através do som do mundo e do som da fala, o Cinema Verdade inaugura a entrevista e o depoimento como elementos estilísticos. (Ramos, 2004: 82).

A chegada do som direto provoca grandes mudanças no documentário brasileiro, não só no aspecto técnico, mas também na temática abordada. Para Consuelo Lins e Cláudia Mesquita (2008), as obras produzidas na época "são filmes que abordam criticamente, pela primeira vez na história do documentário brasileiro, problemas e experiências das classes populares, rurais e urbanas nos quais emerge o 'outro de classe' - pobres, desvalidos, excluídos e marginalizados". Aruanda (1960), Garrincha, a voz do povo (1962), Maioria Absoluta (1964) e Viramundo (1965) são alguns exemplos dos primeiros documentários nacionais produzidos com a nova técnica e com a temática do povo. 
Em um primeiro momento, o documentário nacional não se transforma efetivamente. Podemos observar que a voz do povo se faz presente, através da entrevista, mas ela ainda não é o elemento principal. A narrativa ainda é construída pela voz over ou "voz do saber", e é essa voz que informa o espectador sobre o que é real, sendo a voz do povo utilizada apenas para comprovar o que o locutor está dizendo. Jean-Claude Bernardet (2003) classifica a voz do povo como a "voz da experiência" - experiência real que ilustra o saber científico do narrador. $\mathrm{O}$ autor ainda classifica o modelo desses filmes como "sociológico", uma vez que usa a fala dos entrevistados para exemplificar uma tese já elaborada antes da realização do filme.

Já nos anos 70, mesmo que ainda de forma tímida, o modelo sociológico começa a ser questionado e a voz do outro começa a ter um novo papel nos documentários. Nesse momento, encontram-se "curtas documentais que buscaram 'promover' o sujeito da experiência à posição de sujeito do discurso" (Lins; Mesquita, 2008: 23). Nesse momento, o "outro de classe" passa a ter a missão de produção de sentidos com sua própria experiência. Lins e Mesquita destacam que aqui se radicalizou o ímpeto de "dar a voz". O filme Tarumã (1975), de Aloysio Raulino, é um exemplo dessa ruptura com as características que dominavam o documentário até então.

Ainda na década de 70, o programa de televisão Globo Repórter (Rede Globo) trouxe experiências inovadoras para os documentários. Com produções menos marginais e, até mesmo menos livres do que os filmes independentes, permitiu testar novas formas de abordar a realidade, fugindo da estética padrão da televisão, com apresentador e narrador oficial. Câmera na mão, planossequência, ausência de voz over e personagens que fugiam das tipificações são alguns elementos que davam singularidade às produções do programa, o que abriu novas possibilidades para o documentário da época.

Mas foi, segundo Bernardet, Cabra marcado para morrer (1964/1984), de Eduardo Coutinho, o divisor de águas entre o documentário moderno, das décadas de 60 e 70, e o contemporâneo, dos anos 80 e 90 . O filme indica e sintetiza novos caminhos para o cinema nacional.

Em vez dos grandes acontecimentos e dos grandes homens da história brasileira, ou de fatos e pessoas exemplares, o filme se ocupa de episódios fragmentários, personagens anônimos, aqueles que foram esquecidos e recusados pela história oficial e pela mídia. Cabra marcado efetua desvios significativos nas formas de se fazer documentário no Brasil, mas não deixa de dialogar com diferentes estéticas documentais e da reportagem televisiva, retomando algumas delas e reinventando outras. (Lins e Mesquita, 2008).

Em Cabra marcado, "Coutinho aposta no processo de filmagem como aquele que produz acontecimentos e personagens, aposta no encontro entre 
quem filma e quem é filmado como essencial para tornar o documentário possível" (Lins e Mesquita, 2008). Aqui já podemos observar um modelo de abordagem muito comum no documentário nacional nas décadas de 80 e 90: a entrevista como principal artifício de produção de sentido, em detrimento do uso de narração ou voz over, que ficou cada vez mais escasso, o que apontou para uma nova estética documentária, que se consolidaria ainda mais nos anos seguintes.

Nas décadas seguintes, os documentários afastam-se ainda mais do modelo educativo e panfletário e seguem a tendência das entrevistas, que virou um dos principais artifícios do gênero. Nesse cenário do documentário contemporâneo nacional, o cineasta e diretor Eduardo Coutinho tem papel de destaque. Além da diversidade dos temas retratados, a abordagem e a montagem dos filmes se diferenciam, constituindo um modelo "Coutiniano" de fazer cinema. Bernardet (2003) destaca o uso da entrevista em seus filmes, o que ele considera um estilo.

\section{O documentário de Eduardo Coutinho}

Considerado um dos mais importantes nomes do documentário brasileiro, Eduardo Coutinho nasceu na cidade de São Paulo, em 1933 e faleceu em 2014, assassinado pelo filho, Daniel Coutinho, que sofria de esquizofrenia. Filho de engenheiro e pertencente a uma família tradicional, Coutinho estudou Direito na Faculdade de Direito do Largo de São Francisco, em São Paulo, mas não concluiu o curso. Em 1954, começou a trabalhar como redator e revisor da revista Visão, onde ficou até 1957. Nessa mesma época, conseguiu ganhar dois mil dólares no programa O Dobro ou Nada, da Rede Record, respondendo perguntas sobre Charles Chaplin. Com o dinheiro do programa, viajou para Moscou para participar de um Festival da Juventude. Durante essa viagem, instalou-se em Paris a fim de estudar cinema no IDHEC (Institut des Hautes Études Cinématographiques), conseguindo uma bolsa de estudos. Permaneceu na Europa durante três anos, período em que passa também por uma experiência teatral, dirigindo Pluft, o Fantasminha, de Maria Clara Machado. Em 1960, já de volta ao Brasil, fez assistência de direção na peça $O$ Quarto de Despejo (1960), de Eddy Lima, e integrou-se ao CPC (Centro Popular de Cultura), trabalhando na montagem de peças.

Coutinho teve uma trajetória singular no cinema nacional. Contemporâneo de muitos integrantes do Cinema Novo, amigo e colaborador de alguns deles, como Leon Hirszman e Eduardo Escorel, iniciou sua carreira cinematográfica na ficção. Ao longo da década de 1960, participou de alguns roteiros - como $A$ Falecida (1965), de Leon Hirszman, e Dona Flor e seus dois maridos (1975), 
de Bruno Barreto, - e dirigiu alguns filmes: O Pacto (1966), que foi um dos três episódios de $A B C$ do Amor; o longa metragem $O$ homem que comprou o mundo (1968) e Faustão (1970), que foi sua última experiência com ficção. Por meio do projeto UNE - Volante, passou a documentar as cidades que conhecia. E é nesse período que conhece Elisabeth Teixeira, viúva do líder de ligas camponesas de Sapé, na Paraíba, João Teixeira, morto em uma manifestação, e personagem principal de seu primeiro documentário, Cabra marcado para morrer (1964-1984). "No entanto, na década de 60, o objetivo era realizar uma ficção, utilizando os próprios camponeses. Porém, os militares proibiram a filmagem, e logo depois, o cineasta continuou a realizar outros trabalhos" (Morais, 2012: 108).

Em 1975, o cineasta foi convidado a integrar o núcleo de Jornalismo do Globo Repórter, onde ficou durante nove anos. Durante esse tempo, Coutinho começou a lidar com situações reais do cotidiano, temas que geralmente envolviam cenas dramáticas. Além disso, nesse período, teve a oportunidade de conhecer melhor o Nordeste, visto que filmou na região grande parte dos documentários do programa. Tal experiência contribuiu para que o diretor retomasse a produção do longa metragem Cabra marcado para morrer (1964/1984), que começou a ser filmado na mesma região em 1964, como falado anteriormente. "A película narra a história de Elisabeth Teixeira, que viveu longe de seus filhos. O documentário é considerado um marco no cinema brasileiro, ele ganhou prêmios internacionais" (Morais, 2012: 108). Depois de Cabra, o diretor passou a realizar apenas a produção de documentários em vídeo e roteiros de séries para a TV Manchete.

Ao longo de sua carreira, Eduardo Coutinho começou a usar o termo "dispositivo"para se referir a seus procedimentos de filmagem (Lins, 2004), ou seja, o dispositivo é a forma como determinado universo será abordado no filme e que leva em consideração locação, formato (vídeo ou película), movimentos de câmera e o que vai aparecer na imagem - equipe, ambiente externo, personagem, fotos. Ao analisarmos os filmes de Coutinho, podemos dizer que há procedimentos que se repetem, tornando-se quase que um padrão do cineasta, porém, não se pode afirmar que ele usa um mesmo dispositivo em todos os trabalhos e observamos que, mesmo aqueles que se repetem, são articulados de maneiras diferentes em cada documentário.

Uma das características mais marcantes do dispositivo de Coutinho e que se repete em quase todos os seus trabalhos desde Cabra marcado para morrer (1964/1984) é o modo como ele trabalha a imagem. Observamos que as imagens são, na maioria das vezes, paradas em único ângulo, alternando apenas o enquadramento, às vezes em planos mais abertos, outras, mais fechados. 
Essa ideia de câmera fixa se faz mais presente desde Santa Marta, duas semanas no morro (1987) e se torna praticamente um padrão na obra do cineasta desde então. Coutinho atribui esse tratamento da imagem a sua concepção de documentário como um encontro, pois, para ele, o essencial é a relação entre entrevistador e entrevistado; portanto, é nisso que precisa se concentrar, não podendo se distrair com outras coisas.

No início da filmagem ainda posso observar um, dois tipos de planos que o câmera está usando, depois, nem olho mais para ele. Preciso estar inteiramente entregue a essa ligação, olhando para a pessoa, tentando sentir o que ela está sentindo e tentando passar para ela o que eu estou sentindo, se estou gostando, se não estou gostando. Além do mais, por que mudar a câmera de uma posição para outra? Eu nunca sei realmente o que vai acontecer nesse encontro. Prefiro então que em todos os filmes a câmera fique imóvel; a única mudança se dá em relação ao tamanho da imagem, variando o enquadramento de um close a um primeiro plano ou outro mais aberto. O que depende geralmente da intuição e sensibilidade do fotógrafo porque, como já disse, eu não posso acompanhar. Para mim não adianta uma câmera genial que não escuta. Ele precisa ser tão delicado com o outro como eu sou. Se toda a equipe não estiver entregue, não dá certo. (Figueiroa et al., 2003).

Essa prioridade da relação entre a equipe e o personagem também refletese em outros aspectos da filmagem, como a iluminação, que deve ser simples e rápida, pois, segundo o diretor, se demorar muito deixa o personagem cansado e impaciente. Outro aspecto é a escolha do local onde o entrevistado irá ficar, que deve ser confortável para ele ficar o tempo que for preciso, independente se é bonito ou não. Portanto, a estética é uma coisa secundária, com que ele não se preocupa muito, como podemos ver em seus filmes, que possuem cenários simples e pouca iluminação artificial. Em alguns, ele radicaliza essa ideia, como em Jogo de cena (2007) e As Canções (2011), onde vemos um único cenário, onde há apenas uma cadeira para o entrevistado e um fundo neutro.

Outra característica marcante do dispositivo de Coutinho é a montagem do filme. Já em Theodorico, Imperador do Sertão (1978), o diretor mostrou seu interesse pelo relato das pessoas, desde então seu foco se tornou o "outro", a história que o "outro" tem para contar. Com isso, observamos que a montagem de seus documentários é sempre direcionada para que o relato dos personagens seja o ponto central. Podemos afirmar que, a partir de Santo Forte (1999), essa ideia se tornou mais relevante, uma vez que esse é um filme construído apenas com a fala dos personagens. Entretanto, por ser um filme todo falado, foi considerado por diversos críticos como algo pobre de imagens, do ponto de vista estético. Em Santo Forte, as únicas imagens que não são dos personagens, são as da equipe, as de santos e da visita do Papa ao Rio de Janeiro, em 1997. 
De acordo com Consuelo Lins (2004), esse dispositivo de se montar um documentário apenas com imagens de pessoas falando, que já havia sendo construído anteriormente, se consagrou com o lançamento de Santo Forte. Desde então, o que vemos na maior parte de sua obra são filmes montados unicamente com depoimentos. Essa opção de montagem se dá pelo pensamento de que "a palavra é geralmente mais visceral. E a imagem quando entra, não pode ser adjetiva" (Figueiroa et al., 2003), isto é, quando uma imagem aparece, ela não pode ser apenas uma ilustração do que está sendo falado, como uma prova, ela também precisa contar algo. Além disso, Coutinho também considera que, quando se insere outra imagem durante o depoimento, como uma foto, por exemplo, você quebra o presente, interrompe o momento da fala para inserir algo que não fez parte daquele instante.

Ainda em relação à montagem, outra característica marcante na obra de Coutinho é a presença da equipe nas imagens. Já em Cabra marcado para morrer (1964/1984) podemos ver imagens da equipe chegando ao local das gravações e abordando os personagens, o que se tornou quase que um padrão do diretor. Essa iniciativa de deixar explícito o ato de filmagem está relacionada com a ideia que o diretor tem do documentário como um encontro entre equipe e personagem. "Estamos filmando um encontro sempre: o encontro entre o mundo do cineasta e da sua equipe, mediado pela câmera, e o mundo que está em frente a essa câmera. É por isso que a maioria dos meus filmes começa com a equipe chegando ao local da filmagem" (Figueiroa et al., 2003).

Também temos que destacar a opção de Coutinho pelo uso da gravação em vídeo, ao invés de película. O cineasta considerava o digital um aliado, pois, como seus filmes eram construídos por meio de entrevistas, era preciso uma continuidade, e a película, cuja fita dura onze minutos, "quebraria" a espontaneidade do entrevistado. Para ele, teria sido impossível fazer a maioria dos seus documentários se tivesse que usar película.

Faz parte disso também uma câmera que seja colocada num lugar em que seja possível conversar com essa pessoa durante trinta minutos, uma hora se for preciso. Por isso uso vídeo e seria totalmente impossível usar filme por uma razão que não é só econômica. O filme de $16 \mathrm{~mm}$ tem um chassi de onze minutos de imagem. A pessoa desenvolve uma emoção, pois é mais uma emoção do que um raciocínio, e três minutos depois isso é interrompido, pois é preciso mudar o chassi do filme. É como você querer que uma pessoa retome um coito interrompido, isso jamais vai acontecer. (Coutinho, 2006: 192).

Coutinho considerava crucial a criação do dispositivo a ser usado em um projeto de documentário, pois, segundo o próprio diretor, definir essas características era um dos pontos mais importantes para o sucesso das entrevistas e 
do filme como um todo, sendo até mesmo mais importante do que o tema ou a elaboração do roteiro.

Desde Cabra marcado para morrer ((1964/1984), observamos que a essência das obras de Eduardo Coutinho é a palavra do outro, mas foi em Santo Forte (1999) que essa concepção se consolidou, como vimos anteriormente. Desde então, a montagem de seus filmes se concentrou em apenas entrevistas, com poucas imagens externas. Em alguns filmes, isso fica ainda mais radical, como em As canções (2011) e Jogo de cena (2007), em que não há nenhuma imagem externa, além das entrevistas. Entretanto, é importante ressaltar que o diretor não fazia filmes "sobre os outros", mas sim "com os outros" (Lins, 2004), uma vez que "essa ideia, entre outras coisas, pressupunha uma verdade do outro a ser revelada no filme, pronta para ser extraída pelo documentarista" (Lins, 2004, p. 108), o que condiz com um dos principais princípios de seu cinema, que é a transformação do personagem durante o encontro filmado.

Eduardo Coutinho é uma das maiores referências nacionais quando se fala de documentário de entrevista (Salles apud Lins, 2004). A forma como o diretor a conduz e o modo como a coloca na montagem deram singularidade aos seus filmes, tornando seu modo de entrevistar um estilo, como destacamos no início deste trabalho. O que diferencia o cineasta é o jeito como ele não só conduz, mas como se porta diante do personagem. "Coutinho não é um interlocutor comum porque não está ali para debater o que ela diz, nem dar sua opinião - e é essa atitude o que diferencia totalmente o que ele faz do que em muitos documentários e em matérias para a televisão" (Lins, 2004: 109).

A vitalidade dos depoimentos nos filmes de Coutinho é resultado de um conjunto de fatores. O cineasta sempre evitou a palavra entrevista e procurava chamar o que fazia de conversa; portanto, buscava deixar a situação mais natural e confortável possível, tirando um pouco do ar cinematográfico do ambiente:

O que acontece muito em documentário é que as pessoas armam o set de filmagem. Isso pode levar meia hora, quarenta minutos. Preocupação com luz, enfim uma "estética" que não tem sentido. O que entorna o caldo do outro, é o que interessa. Assim, a primeira coisa é tratá-la como conversa em qualquer situação ou lugar, e torná-la especial. (Coutinho, 2006: 191).

Outro fator muito importante é a postura do diretor durante a entrevista. Ao analisarmos alguns filmes, percebemos que o cineasta quase não interrompe $o$ depoimento, deixando o entrevistado falar livremente e o escutando com atenção - dá tempo para que o personagem formule suas ideias, faz poucas perguntas e respeita os silêncios e pausas. Além disso, Coutinho não faz julgamentos ou contestações em nenhum momento da entrevista, uma vez não busca a verdade sobre algum acontecimento. Ele não quer provar ou comprovar nada, 
seu objetivo é apenas ouvir o que o outro tem para dizer, a história daquela pessoa e sua visão do passado. A única coisa que importa são os relatos dos entrevistados, não há julgamentos de valor, se está certo ou errado.

Para o diretor, o entrevistador tem que estar vazio no momento da entrevista, isto é, tem que deixar suas ideologias e conceitos de lado e apenas ouvir o que o outro diz, sem julgar. Além disso, passar a sensação de que você não espera nada dele, nenhuma resposta específica. O que é de extrema importância para o bom funcionamento desse encontro, pois, assim, você evita objetivar o outro, o que significa, para ele, a morte simbólica do outro, pois o que as pessoas querem é ser reconhecidas e terem uma singularidade no mundo. "Quando a pessoa diz uma coisa e você, enquanto escritor, cineasta, diz, por exemplo: 'Isso é interessante, pois é típico da classe média', pronto, matou o outro" (Coutinho, 2006:194).

Também consideramos importante destacar o papel da personagem. Em um documentário, podemos abordar esse estudo sob diferentes pontos de vista - como sua escolha, seu papel na construção do filme como um todo e as características de sua narrativa. Para Eduardo Coutinho, o principal critério para ser selecionado era saber narrar bem. O que importava era a forma como a pessoa contava sua história - emoção, vocabulário, entonação - o que julgava mais importante do que o próprio conteúdo. "Um cara pode ter uma história banal, mas ser um grande narrador e, por isso, se tornar um grande personagem. Um cara pode ter uma vida extraordinária, e isso já faz dele um personagem, mas precisa saber narrar bem a sua história, senão sai do filme" (Figueiroa et al. , 2003).

Unindo essa condição de ter uma boa narrativa com o pensamento de que o documentário é um encontro mediado pela câmera, Coutinho também considerava essencial a interação do personagem com ele e com a equipe durante a filmagem, pois acreditava que "na interação que se dá no processo de filmagem é que nasce um grande personagem" (Figueiroa et al., 2003).

No centro do seu método, está a fala de alguém sobre sua própria experiência, alguém escolhido porque se espera que não se prenda ao óbvio, aos clichês relativos à sua condição social. $\mathrm{O}$ que se quer é a expressão original, uma maneira de fazer-se personagem, narra, quando é dada ao sujeito a oportunidade de uma ação afirmativa. Tudo o que da personagem se revela, vem de sua ação diante da câmera, da conversa com o cineasta e do confronto com o olhar e a escuta do aparato cinematográfico. (Xavier, 2004: 181).

Eduardo Coutinho acreditava que a relação entre documentarista e entrevistado é construída a partir das diferenças entre eles, "do encontro entre dois mundos socialmente diferentes e da intermediação da câmera" (Figueiroa $e t$ al., 2003), pois, ainda segundo ele, quando essa diferença é reconhecida e 
aceita por ambas as partes, a experiência da filmagem se torna uma experiência de igualdade, contudo, uma igualdade utópica e temporária. Entretanto, o cineasta ressaltava que essas diferenças também exigem que o entrevistador não se sinta superior ao outro só por ter o controle da câmera, que nessa situação de filmagem representa o poder. Além disso, exige também que o documentarista não julgue o outro, o que é de grande importância para estabelecer uma boa relação entre os envolvidos, o que se reflete no bom funcionamento da entrevista. Para o diretor, isso era essencial para que as pessoas aceitassem conversar com ele. "Se as pessoas falam pra mim [...] é porque talvez eu passe um sentimento de que elas não estão lá para serem julgadas. Se elas sentem que estão sendo julgadas, acabou tudo" (Coutinho, 2006: 194).

Portanto, podemos dizer que, em um documentário de entrevista, a relação entre entrevistador e entrevistado e a forma de narrar do personagem são essenciais para um bom resultado, mais até do que o próprio conteúdo, pois, como afirmava Coutinho, o filme só acontece por causa desse encontro. Você pode ter um ótimo tema, mas se não tiver o encontro entre entrevistador e entrevistado, não tem filme.

\section{Jogo de cena e a "performance" na entrevista}

Como vimos anteriormente, a entrevista tornou-se um dos principais artifícios das narrativas audiovisuais. No documentário, essa é uma das maneiras mais comuns de dar voz ao outro, o que contribuiu para a reforçar a ideia de que o gênero é o cinema que trabalha com a realidade - pessoas, situações e histórias reais - diferenciando-o da ficção. Também vimos que a entrevista tornou-se umas das características mais marcantes dos filmes de Eduardo Coutinho, que, já em Theodorico, Imperador do Sertão (1978), demonstrou seu interesse pelo relato das pessoas. Analisamos também que a montagem de seus documentários é sempre direcionada para que a entrevista seja o ponto central - característica que ficou mais forte a partir de Santo Forte (1999), uma vez que a maioria dos filmes que vieram posteriormente foram construídos majoritariamente com cenas dos depoimentos.

Contudo, em Jogo de cena (2007), o diretor traz uma nova perspectiva sobre a entrevista e a relação entre filmes de ficção e de não-ficção. JeanClaude Bernardet afirma que o filme revela uma coragem impressionante, por questionar o documentário de entrevista e a obra do próprio Coutinho.

Jogo de Cena põe em dúvida toda a filmografia de Coutinho desde Santo Forte (uma coragem excepcional). Jogo de Cena põe em dúvida todos os filmes documentários baseados na fala como discurso da subjetividade e no relato de histórias de vida. Põe em dúvida a relação entre o corpo falante e a 
fala da subjetividade (quem emite essa fala? Essa fala fala do quê?). Põe em dúvida a relação entre a fala e a subjetividade. (Bernardet , 2013: 629).

Diante disso, trabalharemos no presente artigo a relação entre ficção e nãoficção a partir da entrevista no filme Jogo de cena, e sob a perspectiva da "performance". Para tal análise, nos basearemos no estudo feito pelo autor Cláudio Bezerra no livro A personagem no documentário de Eduardo Coutinho, aplicando-o ao filme em questão. Para começar, é importante definirmos o conceito de "performance". Bezerra (2014) afirma que é um termo polissêmico e que a falta de um recorte conceitual amplia as possibilidades de interpretação, além de dificultar o entendimento de sua utilização. Por isso, em nossa discussão, nos atentaremos ao conceito como algo do campo artístico e sua abordagem no cinema documental, tomando a definição que "a expressão performance diz respeito à realização de determinados atos em situações definidas, envolvendo certo nível de eficiência em sua execução" (Bezerra, 2014: 50).

Em 2006, Coutinho e sua equipe convocaram, por meio de anúncios em jornais, revistas e na televisão, mulheres maiores de 18 anos, moradoras do Rio de Janeiro, que tivessem histórias para contar e que se interessassem em participar de um teste para um filme documentário. Tal anúncio resultou na inscrição de 83 mulheres, que foram pré-entrevistadas pela editora-assistente. Após esse primeiro contato, 23 depoimentos foram gravados no Teatro Glauce Rocha, no Rio de Janeiro, com o diretor, que não teve contato com as préselecionadas antes desse momento. Posteriormente, Coutinho selecionou atrizes profissionais e pediu que cada uma interpretasse um dos depoimentos filmados, com liberdade para seguir os próprios instintos. Cada atriz recebeu o vídeo do depoimento que deveria interpretar. Logo em seguida, no mesmo teatro, o diretor gravou as atrizes - algumas delas conhecidas do grande público, como Fernanda Torres, Marília Pêra e Andréa Beltrão, e outras desconhecidas. No longa-metragem, lançado em 2007, as histórias são contadas duas vezes, uma pelas personagens reais, e outra por atrizes, não deixando claro para o espectador quem está contando sua própria história e quem está interpretando, construindo assim o jogo de cena.

Jogo de cena (2007) começa com a chegada de Sheila, que sobe a escada até chegar ao palco onde Coutinho e sua equipe a esperam. Sentada na cadeira do entrevistado, de costas para a plateia vazia, inicia seu depoimento sobre sua pretensão de ser atriz desde muito jovem, o que achava inviável devido a suas características físicas e à falta de formação, e como ingressou no grupo de teatro Nós do Morro, da favela do Vidigal. No decorrer da entrevista, conta que veio a trabalhar na peça Gota D'água, de Chico Buarque e Paulo Pontes, 
fazendo o papel principal. Nesse momento, Coutinho pede que ela encene uma parte da peça. Ismail Xavier (2012) considera o teor dessa entrevista irônico, pois, "de imediato, ela nos traz uma narradora-atriz que, embora fale de si e nos convença de que a história é sua, já aponta o problema da competência de atriz e seus requisitos" (Xavier, 2012: 614). O autor também considera que essa abertura já lança as questões da representação e da "performance". Mais adiante no filme, o espectador verá novamente essa história, mas contada por Jeckie Brown, o que o deixará em dúvida sobre qual das duas é a atriz que está interpretando.

Logo em seguida, vem a longa entrevista de Gisele, que, a partir de determinado momento, é intercalada com o depoimento da atriz Andréa Beltrão, ambas contando a mesma história. Podemos dizer que neste momento começa o jogo, pois ao se deparar com duas mulheres contando a mesma história, de forma alternada, e sendo uma delas uma atriz de televisão, conhecida pelo público, o espectador começa a questionar se as histórias contadas são verdadeiras e a quem elas pertencem. Nesse momento, o status de verdade da entrevista também começa a ser questionado e entra a questão da "performance". Se analisarmos o relato de cada uma, podemos observar que, em determinados momentos, Andréa se emociona e chora até mais do que Gisele, o que nos faz duvidar se aquela história não pode realmente ser da própria atriz. Nesse momento, o filme já nos leva a pensar que em uma entrevista não se pode levar em consideração apenas a história que está sendo narrada, mas como ela está sendo narrada, isto é, toda a construção narrativa.

Ao abolir o texto narrativo e a rígida construção de personagens do teatro convencional, a performance aciona um espetáculo de efeitos visuais, em que se destaca a atuação do artista-performer. Mais importante do que aquilo que se diz é o 'como' se diz. A história é secundária, e o interesse do espectador recai para o que 'está sendo feito' no momento da apresentação. (Bezerra, 2014: 53).

No final do relato de Andréa, Coutinho a questiona sobre o que ela sentiu e como ela se preparou, evidenciando para o espectador que aquela história não a pertencia. Nesse momento, a atriz revela que não pretendia chorar, pois queria imitar fielmente Gisele, manter a mesma serenidade.Contudo, ela não consegue, pois acha o texto muito forte etem dificuldade de não se emocionar. Com esse relato de Andréa, podemos perceber uma dificuldade da mesma em se distanciar da personagem, de fazer algo mecânico, sem subjetividade, o que nos leva a outra questão importante de ser observada em Jogo de cena, a representação. Bezerra (2014) aborda a questão a partir das técnicas do autor Constantin Stanislavski (1992), que defendem que: 
Quanto mais o ator se anula como pessoa e mergulha na personagem, mais reforça a ficção e a ilusão de ser um "outro". O termo que caracteriza esse procedimento adotado pelo ator chama-se "representação". Ao interpretar ou ceder seu corpo a um determinado papel, o ator teatral procura compor ou reapresentar o que supõe estar implícito ou explícito no texto de uma peça, e quase sempre segue as orientações bem-marcadas do diretor. (Stanislavski apud Bezerra, 2014: 53).

A partir disso, podemos encontrar uma dualidade no filme - que fica explícita com a reflexão de Andréa Beltrão -, pois ao mesmo tempo em que ela está ali representando uma personagem, sendo fiel ao texto e tentando seguir as orientações passadas anteriormente pelo diretor, ela não consegue deixar de lado suas emoções pessoais, sua subjetividade, o que é comum quando se trata de "performance", visto que "no caso da performance, tem-se uma passagem tênue da 'representação' para a 'atuação', porque o performer não encarna um tipo ou personagem exterior a si mesmo. Não se anula em prol de um outro 'ser' fictício; é sempre ele, em pessoa, que está atuando" (Bezerra, 2014: 53).

A entrevista que vem em seguida também pode ser considerada outro ponto-chave do documentário. A participação de Maria Nilza reforça a questão de que não devemos apenas considerar a história contada, mas todos os elementos narrativos. $\mathrm{O}$ fato de ser um rosto até então desconhecido e toda a construção da personagem - vestimentas, maquiagem, expressões, modos de falar, gestos e até mesmo o vocabulário - nos levam a acreditar que se trata de uma não-atriz e que ela está ali contando sua história pessoal.Nesse momento, entra outro elemento importante nessa relação se é representação ou não, os estereótipos; pois tal julgamento que o espectador faz também está imbricado com os estereótipos definidos em nossa sociedade - nesse caso da mulher negra, pobre, que usa roupas curtas, maquiagens chamativas e que trabalha como empregada doméstica. Entretanto, ao final do depoimento, quando ela olha diretamente para a câmera e diz "foi isso que ela disse", desconstrói esse préjulgamento de que ela não era atriz e reforça ainda mais a dúvida do espectador em relação à participação das próximas mulheres, se são elas atrizes representando ou mulheres anônimas contando suas próprias histórias.

A atriz Fernanda Torres aparece em cena em dois momentos distintos. Sua primeira aparição é logo depois de Maria Nilza, contando uma história de adolescente sobre a visita a um terreiro de umbanda. Esse relato é único, o que gera mais uma confusão ao espectador, pois em nenhum outro momento aparece outra mulher contando a mesma história, quebrando a ideia de que as atrizes conhecidas estão sempre representando e levantando a questão se aquele relato não foi mesmo uma experiência da própria Fernanda. 
Sua outra participação é intercalada com o depoimento de Aleta, uma nãoatriz. Contudo, diferentemente dos depoimentos de Andréa Beltrão e Gisele, nesse momento, a representação de Fernanda fica mais explícita logo no início, pois, na primeira aparição, ambas tem as mesmas atitudes, chegam ao palco, cumprimentam o diretor e falam a mesma frase, que ali havia muita gente. Logo quando começa a falar, a atriz interrompe o relato e diz ao diretor que não consegue fazer, pois tem a sensação que está mentindo para ele e que fica com vergonha, pois tenta imitar ao máximo Aleta, porém não consegue separar a moça e a história. Em seguida, Fernanda volta a representação, alternando com as cenas de Aleta. Ao final, a atriz e Coutinho voltam a falar sobre sua "performance", os elementos pessoais que ela colocou e o que imitou exatamente igual à verdadeira dona da história, o que nos leva novamente para a questão da subjetividade das atrizes ao representar e dos limites entre representação e atuação.

A questão da representação e da subjetividade das atrizes nos é colocada novamente com a participação de Marília Pêra, outra atriz de televisão, conhecida do grande público. A aparição da atriz é alternada com o depoimento de Sarita Houli. Na representação de Marília, vemos uma diferença em relação às de Andréa Beltrão e Fernanda Torres. Enquanto nos é possível ver semelhanças na "performance"das duas atrizes famosas com as das personagens reais e ambas afirmar que buscaram tal aproximação, observamos que Marília traz uma forma de narrar diferente de Sarita. Enquanto a não-atriz tem um jeito mais extrovertido, um tom de voz mais alto e gesticula bastante, a atriz narra de forma mais contida, séria, com tom de voz ameno e poucos gestos. Outra diferença é que nesse momento os depoimentos não são contínuos, elas narram partes diferentes da história e, somente a partir de determinado momento, percebemos uma confluência no que as duas dizem, concluindo que se trata do mesmo depoimento. Ao final do relato, Coutinho e Marília Pêra também fazem uma reflexão sobre a participação da atriz, e ela revela que ao falar sobre a filha de Sarita, ela se lembrou de sua própria filha, o que lhe trouxe emoção e que houve uma mistura de memórias. Aqui retornarmos a dualidade entre a representação e a atuação comum na "performance", pois a atriz foi fiel ao texto da personagem, mas não anulou seu lado pessoal, principalmente nos momentos em que foi remetida a sua relação com a filha, o que lhe causou emoção, dando certa subjetividade a sua interpretação.

O filme segue com as entrevistas de mulheres anônimas e participação de atrizes, contudo, sem nenhuma outra atriz famosa. Alguns depoimentos são repetidos por duas personagens, outros vêm sozinhos, contados apenas por 
uma única pessoa. O espectador segue no jogo entre real e ficção, incerto de quem é atriz e quem não é, e quem é a verdadeira dona da história.

O autor João Luiz Vieira observa em seus estudos sobre as relações entre "performance"e cinema, que "a noção de performance, necessariamente, se amplia para incluir, além do corpo natural, a própria câmera cinematográfica" (Vieira apud Bezerra, 2014: 54). Baseando-se nesses estudos, Bezerra completa que, para entender a inscrição da "performance" no documentário, é preciso conhecer o dispositivo do filme, isto é, conhecer como o filme foi feito. "Ora, para manter o frescor da filmagem no filme, é preciso considerar, além da presença da câmera, todo o dispositivo cinematográfico (equipe, equipamentos, locação, montagem, projeção, espectador, etc.)" (Bezerra, 2014: 54).

Já falamos anteriormente sobre o dispositivo de Coutinho, em que alguns procedimentos se repetem, porém, são articulados de maneiras diferentes em cada filme. Uma das características mais marcantes é o modo como trabalha a imagem, que é, na maioria das vezes, parada, em um único ângulo, mudando apenas o enquadramento, às vezes em planos mais abertos e, em outros momentos, mais fechados. A câmera fixa também é outro elemento presente nos filmes de Coutinho. Em Jogo de cena, podemos observar tais características, que ajudam a compor a narrativa como um todo, dando certa dramatização aos depoimentos.Outro aspecto importante no dispositivo de Coutinho, e que se faz presente no filme em questão, é o cenário, que é simples e o mesmo para todas as personagens. No entanto, nesse caso, o cenário também tem um significado particular, pois o palco do teatro e a plateia vazia reforçam o jogo entre realidade e ficção, uma vez que o teatro é associado a interpretações de textos fictícios por atores profissionais.

A montagem também tem um significado particular em Jogo de cena. Podemos dizer que ela é uma das principais responsáveis pelo jogo feito com o espectador, pois, ao colocar duas mulheres contando a mesma história, sendo uma delas uma atriz famosa, depoimentos de famosas sozinhos, assim como de desconhecidas, sem outra repetição e duas mulheres de rostos desconhecidos do público contando a mesma história em momentos diferentes do filme, o diretor está nos colocando no campo da incerteza e do questionamento. Além disso, também observamos que a montagem não segue um padrão, as entrevistas aparecem em cena de formas diferentes - umas já começam direto com o depoimento, outras mostram a chegada da entrevistada, umas são continuidade da outra, outras contam partes diferentes da mesma história - o que também reforça esse jogo com quem está assistindo.

Variantes da montagem do filme articulam de outras formas a inserção das entrevistas nessa dinâmica de identidade e diferença, evidenciando o quanto a performance das personagens que falam de si em chave autobiográfica e as 
que resultam do trabalho de atrizes desconhecidas que interpretam a partir de um script produzem o mesmo efeito de verossimilhança, autenticidade e convencimento. (Xavier, 2012: 619).

A construção narrativa de Jogo de cena apresenta traços comuns do cinema de ficção, como o cenário, o uso de atrizes profissionais e o drama. Entretanto, o filme não perde o caráter documental, ao trazer depoimentos de histórias de vida, principal característica dos filmes de Coutinho. No longa-metragem, o diretor coloca em jogo a questão da verossimilhança do real e não a da verdade.

\section{Considerações finais}

A entrevista é a principal maneira de dar voz ao outro no documentário, tornando-se o ponto central da narrativa documental. Além disso, ao longo do tempo, passou a ser vista como um artifício de veracidade, reforçando a ideia de que o que está sendo dito naquele depoimento é verdade, que aquela história é real e que a pessoa que está contando não está interpretando um personagem. Entretanto, Eduardo Coutinho coloca em seus filmes a entrevista como a porta de entrada para a ficção, pois, nos depoimentos dados diante da câmera, os entrevistados representam e atuam, construindo situações que não seriam as mesmas que no mundo real, sem a presença do aparato cinematográfico.

Jogo de cena (2007) reforça essa dúvida do status de real da entrevista e do documentário. Ao trazer mulheres anônimas, atrizes famosas e outras não tão famosas, o diretor nos faz questionar se aquilo que está sendo contado é mesmo verdade e se aquela história pertence àquela pessoa que está contando, se a pessoa está interpretando uma personagem ou atuando como ela mesma. O filme nos faz repensar sobre a veracidade dos depoimentos presentes em outros documentários de entrevista, inclusive do próprio Coutinho.

Jogo de cena (2007) se torna um filme ainda mais emblemático ao apresentar uma dualidade, pois utiliza atrizes profissionais interpretando certos papéis, mas que também, em dadas situações, atuam como performers, isto é, colocam seu lado pessoal, sua subjetividade, na representação, principalmente quando falam de suas próprias experiências de vida, assim como as mulheres anônimas. Não há uma regra definida de quem está representando uma personagem e de quem está atuando como ela mesma, e é essa indefinição que leva o espectador ao jogo.

Com o estudo dos depoimentos de Jogo de cena, observamos que a veracidade de uma entrevista, principalmente em documentários, não pode ser considerada apenas pelo conteúdo que está sendo narrado ou por quem está narrando, mas por toda a construção narrativa que a envolve, como a forma de narrar - gestos, expressões, vocabulário, entonação, emoção - e o disposi- 
tivo usado - equipe, equipamentos, cenário, iluminação, montagem. Também observamos que os limites entre ficção e documentário são muito tênues, não podendo ser vistos como algo bem definido, pois características de um gênero pode transitar dentro do outro.

\section{Referências Bibliográficas}

Bernardet, J. - C. (2003). Cineastas e imagens do povo. São Paulo: Companhia das Letras.

Bernardet, J. - C. (2013). Jogo de cena. In M. Ohata (org.), Eduardo Coutinho (pp. 627-636). São Paulo: Cosac Naify.

Bezerra, C. (2014). A personagem no documentário de Eduardo Coutinho. Campinas: Papirus.

Coutinho, E. (2006). Na altura do olho. In K. Worcman, \& J. V. Pereira (coord.), História falada: memória, rede e mudança social. São Paulo: SESC SP: Museu da Pessoa: Imprensa Oficial do Estado de São Paulo, ISBN: 85-98112-21-6.

Figueirôa, A.; Bezerra, C. \& Fechine, Y.(2003). O documentário como encontro: entrevista com Eduardo Coutinho. Galáxia: Revista do Programa de Pós-Graduação em Comunicação e Semiótica, vol. 6. PUC-SP. São Paulo, ISSN: 1982-2553. Disponível em: https://revistas.pucsp.br/index.p $\mathrm{hp} /$ galaxia/article/view/1348

Lins, C. (2004). O documentário de Eduardo Coutinho: televisão, cinema e vídeo. Rio de Janeiro: Ed Zahar.

Lins, C. \& Mesquita, C. (2008). Filmar o real:o documentário brasileiro contemporâneo. Rio de Janeiro, Ed. ZAHAR.

Morais, T. (2012). O estatuto da ficção no documentário Jogo de cena de Eduardo Coutinho. In B. Lira (org.), Documentário e modos de representação do real. João Pessoa, Marca de Fantasia. Disponível em: www.scientia.uf pb.br/omp/index.php/elivre/catalog/view/47/42/95-1.

Musse, C. F. \& Musse, M. F.(2010). A entrevista no telejornalismo e no documentário: possibilidade e limitações. Disponível em: www.revistas.usp.b r/Rumores/article/view/51209

Musse, M. F. (2012). Margens nada plácidas: documentário, entrevista, identidades e alteridade. Dissertação de Mestrado, Faculdade de Comunicação, Universidade Federal de Juiz de Fora.

Nichols, B. (2007). Introdução ao documentário. 2. Ed. São Paulo: Papirus. 
Ramos, F. P. (2008). Mas afinal... O que é mesmo documentário?. São Paulo: Ed. Senac.

Ramos, F. P. (2004). Cinema verdade no Brasil. In F. E. Teixeira, Documentário no Brasil: tradição e transformação (pp. 81-96). São Paulo: Summus.

Xavier, I. (2013). Jogo de Cena e as outras cenas. In M. Ohata (org.), Eduardo Coutinho (pp.604-626). São Paulo: Cosac Naify.

Xavier, I. (2004). Indagações em torno de Eduardo Coutinho e seu diálogo com a tradição moderna. Comunicação e Informação, 7(2): 180-187. UFG-GO, Goiás. Disponível em www.revistas.ufg.br/ci/article/view/2430 $4 / 14101$

\section{Filmografia}

Jogo de cena (2007), de Eduardo Coutinho. 